\title{
Eutrophication: are mayflies (Ephemeroptera) good bioindicators for ponds?
}

\author{
N. Menetrey - B. Oertli - M. Sartori - A. Wagner · \\ J. B. Lachavanne
}

(C) Springer Science+Business Media B.V. 2007

\begin{abstract}
Ephemeroptera larvae are recognized worldwide for their sensitivity to oxygen depletion in running waters, and are therefore commonly used as bioindicators in many monitoring programmes. Mayflies inhabiting lentic waters, like lakes and ponds, in contrary have been poorly prospected in biomonitoring. For this purpose, a better understanding of their distribution in lentic habitats and of the relations of species presence with environmental conditions are needed. Within this framework, 104 ponds were sampled in Switzerland. The Ephemeroptera are found to be an insect order particularly well represented in the ponds studied here $(93 \%$ of the lowland ponds). Nevertheless, in terms of diversity, they are relatively poorly represented (mean
\end{abstract}

Guest editors: R. Céréghino, J. Biggs, B. Oertli \& S. Declerck The ecology of European ponds: defining the characteristics of a neglected freshwater habitat

N. Menetrey $(\varangle) \cdot$ J. B. Lachavanne

Laboratory of Ecology and Aquatic Biology,

University of Geneva, Ch. des Clochettes 18,

1206 Geneva, Switzerland

e-mail: nathalie.menetrey@leba.unige.ch

B. Oertli

Ecole d'Ingénieurs de Lullier, University of Applied

Sciences of Western Switzerland, 150 rte de Presinge,

1254 Jussy, Geneva, Switzerland

M. Sartori · A. Wagner

Museum of Zoology, Place Riponne 6, 1014 Lausanne,

Switzerland species number $=1.9$ ). Two species dominated: Cloeon dipterum (Baetidae) and Caenis horaria (Caenidae). The investigations contributed to the updating of the geographical distribution of the species in Switzerland, as many of the observations appear to be from new localities. The trophic state of ponds appears here to be important for Ephemeroptera communities. First, there is a negative relationship between total phosphorus (TP) concentrations and species richness. Second, the presence of Caenis horaria or Cloeon dipterum is dependent on the trophic state. Caenis horaria is most closely associated with low levels of TP concentrations, while Cloeon dipterum appears to be less sensitive, and is most frequently found in hypertrophic conditions. A probable consequence of these relations, is that Baetidae are always present when Caenidae are also present. Contrastingly, Baetidae is observed as the only mayflies family present in several ponds.

Keywords Ephemeroptera larvae .

Aquatic macroinvertebrates - Small waterbodies . Eutrophication · Water quality · Biomonitoring

\section{Introduction}

Mayflies are considered as "keystone" species and their presence is believed to be an important environmental indicator of oligotrophic to mesotrophic (i.e. low to moderately productive) conditions in 
running waters (Barbour et al., 1999; Bauernfeind \& Moog, 2000). A high sensitivity of mayfly taxa to oxygen depletion, acidification, and various contaminants including metals, ammonia and other chemicals was demonstrated in both observational and experimental studies (Hubbard \& Peters, 1978; Resh \& Jackson, 1993; Moog et al., 1997; Hickey \& Clements, 1998). Various Biological Indices including mayflies to assess water quality have been developed over the years (Lenat, 1988; Metcalfe, 1989; Kerans \& Karr, 1994). Subsequently, many of the biological water quality assessment methods for streams include Ephemeroptera, as for example the EPT (Ephemeroptera + Plecoptera + Trichoptera) taxa richness (Lenat \& Penrose, 1996) which has been incorporated into studies in the United States and in many other countries. Other examples include the River InVertebrate Prediction and Classification System (RIVPACS) for the UK (Wright et al., 1998) and the Indice Biologique Global Normalisé (IBGN) for France (AFNOR, 1992). A major EU project with 14 participating member states entitled STAndardisation of River Classifications (STAR) has now been established, which will calibrate different biological survey results against ecological quality classifications that have to be developed for the Water Framework Directive of 2000 (Furse et al., 2006).

On the contrary, mayflies inhabiting lentic waters (e.g. lakes and ponds), have been poorly used in biomonitoring programmes (see however Madenjian et al., 1998). Nevertheless, in such environments, we could expect that mayflies also adequately integrate some aspects of water quality. Ephemeroptera have also other advantages for monitoring: they are highly visible, relatively easy to sample and are represented by only a few species in such habitats, which makes identification easier. In Lake Erie, Ephemeroptera are successfully used in biomonitoring, following the example of a recent study that showed burrowing mayfly nymphs (Hexagenia spp.) to be associated with an improvement of the ecosystem health (Schloesser \& Nalepa, 2002). In smaller waterbodies like ponds, the water quality is rarely assessed. Nevertheless, with the implementation of the directive, such procedures will be developed. This is already the case in some European states (UK, see Biggs et al., 2000; Catalonia, see Boix et al., 2005; Switzerland, see Menetrey et al., 2005).
For the purpose of better understanding the importance of Ephemeroptera in the assessment of water quality in lentic habitats and especially in ponds, a better understanding is needed of: (i) the distribution of mayflies in such habitats and (ii) the relations of species presence with environmental conditions. In this study, the distribution of mayflies is investigated for 104 ponds from Switzerland. In a second step, their presence is assessed in relation to environmental variables, particularly the trophic state indicators (total phosphorus (TP), total nitrogen (TN) and conductivity). Finally, we will examine whether a new metric using Ephemeroptera can be proposed for inclusion in rapid bioassessments methods for swiss ponds.

\section{Materials and methods}

\section{Study area}

Table 1 shows the location of the 104 permanent small water bodies sampled within the following four altitudinal vegetation belts in Switzerland: colline, montane, subalpine, and alpine. They vary in size from $5 \mathrm{~m}^{2}$ to 10 ha (Table 2), with a mean depth comprising between 15 and $910 \mathrm{~cm}$. We will further refer to these small water bodies as "ponds", since most of them correspond to the criteria of the definition of a pond presented by Oertli et al. (2005a). Only one third of these ponds are known to have a natural origin with an age exceeding 4,000 years (last glacial retreat). The others, with

Table 1 Number of sampled ponds per altitudinal vegetation belt (colline (200-800 m), montane (600-1,400 m), subalpine $(1,300-2,000 \mathrm{~m})$, alpine $(>1,800 \mathrm{~m})$ ) and trophic state (based on the concentration of total phosphorus (TP) and total nitrogen (TN) as described by OECD (1982) and Wetzel (1983)

Colline Montane Subalpine Alpine $n=$ total of ponds

\begin{tabular}{lcccrr}
\hline Oligotrophic & $1(1)$ & $1(1)$ & $1(1)$ & $11(2)$ & $14(5)$ \\
Mesotrophic & $4(4)$ & $7(7)$ & $9(4)$ & $6(1)$ & $26(16)$ \\
Eutrophic & $19(19)$ & $12(11)$ & $0(0)$ & $1(0)$ & $32(30)$ \\
$\begin{array}{l}\text { Hypertrophic } \\
\text { 20(17) }\end{array}$ & $7(5)$ & $4(3)$ & $1(0)$ & $32(25)$ \\
$\begin{array}{l}n=\text { total of } \\
\text { ponds }\end{array}$ & $44(41)$ & $27(24)$ & $14(8)$ & $19(3)$ & $104(76)$ \\
\hline
\end{tabular}

In brackets: number of ponds of each type containing Ephemeroptera 
various ages (1-900 years), are artificial, linked to past or present human activities (gravel or clay extraction, fish production, nature conservation, etc.). The range of altitude is from 210 to $2,757 \mathrm{~m}$. The trophic state varies between oligotrophic and hypertrophic (Table 1). Additionally, each pond was characterised with environmental and geo-morphological data (Table 2) (site details are available on request).

\section{Sampling}

Each pond was sampled once during the summer months (June to early August) from 1996 to 2005 following the PLOCH method (Oertli et al., 2005b). Mayflies were collected using a small hand-net (rectangular frame $14 \times 10 \mathrm{~cm}$, mesh size $0.5 \mathrm{~mm}$ ). For each sample, the net was swept intensively through the pre-selected dominant habitats for $30 \mathrm{~s}$. In all cases, the collected material was preserved in either $4 \%$ formaldehyde or $70 \%$ alcohol solutions and then sorted in the laboratory.

Table 2 Mean values and ranges of selected variables characterising the 104 ponds

\begin{tabular}{|c|c|c|c|c|}
\hline & Mean & Median & Minimum & Maximum \\
\hline Altitude (m a.s.1.) & 1069 & 733 & 210 & 2757 \\
\hline Area $\left(\mathrm{m}^{2}\right)$ & 8619 & 2328 & 6 & 96200 \\
\hline Mean depth $(\mathrm{cm})$ & 175.5 & 113 & 15 & 910 \\
\hline Maximal depth $(\mathrm{cm})$ & 343 & 210 & 40 & 2400 \\
\hline Age (years) & 1258 & 68 & 1 & 4000 \\
\hline $\begin{array}{l}\text { Total nitrogen }(\mathrm{TN}) \\
(\mathrm{mg} \mathrm{N} / \mathrm{l})\end{array}$ & 1.07 & 0.55 & 0.04 & 8.79 \\
\hline $\begin{array}{l}\text { Total phosphorus (TP) } \\
\quad(\mu \mathrm{g} \mathrm{P} / 1)\end{array}$ & 65 & 26 & 1 & 611 \\
\hline Conductivity $(\mu \mathrm{S} / \mathrm{cm})$ & 350 & 360 & 3 & 1367 \\
\hline $\begin{array}{l}\text { Hardness } \\
\qquad\left(\mathrm{CaCo}_{3} \mathrm{mg} / \mathrm{l}\right)\end{array}$ & 174 & 175 & 0.8 & 884 \\
\hline $\begin{array}{l}\text { Transparence } \\
\quad(\text { Snellen, } \mathrm{cm})\end{array}$ & 44 & 54 & 3 & 60 \\
\hline $\begin{array}{l}\text { Number of habitats } \\
\text { sampled }\end{array}$ & 4 & 4 & 1 & 9 \\
\hline $\begin{array}{l}\text { Sinuosity of the } \\
\text { shoreline }\end{array}$ & 1.5 & 1.3 & 1 & 3.3 \\
\hline $\begin{array}{l}\text { Macrophyte species } \\
\text { richness }\end{array}$ & 11 & 10 & 0 & 34 \\
\hline $\begin{array}{c}\text { Macroinvertebrate } \\
\text { family richness }\end{array}$ & 19 & 18 & 3 & 44 \\
\hline
\end{tabular}

The physico-chemistry of the water was measured during winter and summer months, as described by Oertli et al. (2000), by establishing a profile using WTW field probes down to the deepest point of the pond (to measure conductivity, $\mathrm{pH}$ and oxygen concentration). The transparency was additionally recorded from a surface water sample using a Snellen tube. Laboratory analyses of the content of TP and TN were made with winter water samples. TP concentrations and TN concentrations were then used to classify each pond into one of the four following trophic categories: oligotrophic, mesotrophic, eutrophic or hypertrophic, as described by the Organization for Economic Cooperation and Development (1982) and Wetzel (1983).

\section{Statistical analyses}

Statistical analyses were performed exclusively on 71 out of the 104 ponds from the colline and montane vegetation belts. The remaining 33 ponds from the subalpine and alpine belts were excluded from this dataset because of the particularity of their mayfly assemblages: only 11 ponds contained Ephemeroptera (Table 1). In addition, Cloeon dipterum and Caenis horaria, the two most abundant species present in many lowland ponds, were much less common at these altitudes. Indeed, most of the mayflies that are present in the subalpine and alpine belts were rare species.

A between-class Principal Component Analysis (PCA) was performed to test if there was an overall difference between the ponds containing Caenidae + Baetidae (33 ponds) and those with Baetidae only (31 ponds) for 12 relevant selected environmental and physico-chemical variables. Three of these variables were log-transformed: area, mean depth and sinuosity of the shoreline; five were transformed in categories: TP, TN, conductivity, transparency and altitudinal vegetation belt; and the last four were not transformed: presence versus absence of fishes, \% of natural zone surrounding the waterbody, $\%$ of catchment area and macrophytes species richness.

A non-parametric Mann-Whitney $U$ test was conducted to test if there was a significant difference for three trophic state variables considered separately (concentrations of TP, TN or conductivity) between 
ponds where Cloeon dipterum or Caenis horaria were present or absent, respectively. In addition, a non-parametric Mann-Whitney $U$ test was performed to analyse the differences in the mayfly species richness between groups of ponds based upon their trophic state (being defined separately by $\mathrm{TP}, \mathrm{TN}$ or conductivity values).

Furthermore, Generalized Additive Models (GAMs) were used to model the occurrence of Cloeon dipterum, or of Caenis horaria with the purpose of (i) identifying the physico-chemical and environmental variables explaining the presence of these species in the ponds, and (ii) building predictive models of their occurrence. GAMs are nonparametric regressions that lead to complex response curves, which differ from the linear and parabolic responses; therefore, non-normally distributed data (including binomial distributions) can be modelled. GAMs were carried out with S-PLUS software using a set of functions developed to perform generalized regression analyses and spatial predictions (GRASP) (Lehmann et al., 2002). After an exploratory stepwise procedure of the same twelve selected variables as the ones taken for PCA, the least contributive were discarded to avoid an over-parameterization of the models. This means that the final model was built around the five most relevant variables: altitude, $\log$ of area, TP (expressed as four trophic categories), log of mean depth, and macrophytes species richness.

The diagnostic procedure for the GAMs included: (1) the most relevant variables retained in the two final regression models at $P=0.05$ level, (2) the contributions of each explanatory variable expressed as a deviance reduction associated to dropping the variable from the model, (3) the percentage of the deviance explained by the models, (4) a linear correlation ratio $(r)$ between observed and predictive values derived from a cross-validation procedure.

\section{Results}

Ephemeroptera species distribution in ponds

Mayflies were found to be present in 76 of the 104 sampled ponds. Of the 85 species (and 11 families) of Ephemeroptera present in Switzerland, 12 species from five families were identified (Table 3 ). This list included logically a majority of lentic species; however, lotic species were also found to be present (i.e. Baetis rhodani, Centroptilum luteolum, Ephemera danica and Siphlonurus aestivalis), which could be explained by the presence of tributaries. The lotic species Baetis alpinus was additionally found in one alpine pond, and this independently of the presence of a tributary. An explanation for the presence of lotic species in lentic ecosystem is that in alpine ponds, the physico-chemical conditions (oxygen, nutrient content, $T^{\circ} \mathrm{C}$ ) are similar to those observed in streams (Hieber et al., 2005).

Amongst the 12 identified species, four are mentioned in the red list of threathened species for Switzerland (Sartori et al., 1994): Centroptilum luteolum, Cloeon simile, Ephemera danica (all three potentially endangered) and Siphlonurus aestivalis (endangered). The finding of Habrophlebia fusca was a first for Switzerland, while Habrophlebia lauta was observed for the first time in the Canton of Graubünden.

The 28 ponds where Ephemeroptera were absent included a set of ponds situated at an altitude over $1,410 \mathrm{~m}$ (22 ponds) or another set with hypertrophic conditions (six ponds). However, mayflies were not always absent from ponds with hypertrophic conditions. Baetidae were observed in 26 hypertrophic ponds, and of these, 15 ponds also contained Caenidae. Likewise, mayflies were not always absent from ponds over an altitude of 1,410 m: nine ponds over $1,410 \mathrm{~m}$ contained mayflies, mostly from the Baetidae or Caenidae families.

When present in a pond, the Ephemeroptera community diversity was low (see Table 3 and Fig. 1) and composed of only a few taxa (mean species number $=1.9$ and mean family number $=1.6)$. The dominant lentic species were Cloeon dipterum (in $93 \%$ of the ponds containing Ephemeroptera) and Caenis horaria (in 45\%). In $43 \%$ of the cases, ponds included only one family, generally the Baetidae with, in most of these cases, Cloeon dipterum being found alone. Otherwise, there was one case each where Cloeon simile was found alone or both together with Cloeon dipterum. For $55 \%$ of the ponds containing Ephemeroptera, two families were recorded, with Baetidae (Cloeon dipterum) present in all cases. One pond included three families. Therefore, Baetidae appeared as the most common mayfly family to be found in Swiss ponds. An interesting observation was that Caenidae were 
Table 3 List of the 12 Ephemeroptera species sampled in 104 ponds from Switzerland, with frequency of observation and altitudinal range

\begin{tabular}{|c|c|c|c|c|c|c|}
\hline \multirow[t]{2}{*}{ Families } & \multirow[t]{2}{*}{ Species } & \multirow{2}{*}{$\begin{array}{l}\text { Current } \\
\text { (preference) }\end{array}$} & \multirow{2}{*}{$\begin{array}{l}\text { nb of } \\
\text { ponds }\end{array}$} & \multirow{2}{*}{$\begin{array}{l}\text { Red } \\
\text { list }\end{array}$} & \multicolumn{2}{|c|}{ Altitudinal range $(\mathrm{m})$ in Switzerland } \\
\hline & & & & & $\begin{array}{l}\text { Known (Sartori \& } \\
\text { Landolt, 1999) }\end{array}$ & $\begin{array}{l}\text { Observed } \\
\text { (our study) }\end{array}$ \\
\hline \multirow[t]{5}{*}{ Baetidae } & Baetis rhodani (Pictet, 1843) & lo & 2 & nd & $200-1900$ & $458-910$ \\
\hline & Baetis alpinus (Pictet, 1843) & lo & 1 & nd & $200-2600$ & 2191 \\
\hline & Centroptilum luteolum (Müller, 1776) & lo & 1 & 4 & $300-1100$ & 910 \\
\hline & Cloeon dipterum (Linné, 1761) & le & 71 & nd & $300-1500$ & $210-1855$ \\
\hline & Cloeon simile (Eaton, 1870) & le & 9 & 4 & $300-1000$ & $350-1813$ \\
\hline \multirow[t]{3}{*}{ Caenidae } & Caenis horaria (Linné, 1758) & le & 34 & nd & $200-1200$ & $210-1813$ \\
\hline & Caenis luctuosa (Burmeister, 1839) & le & 6 & nd & $300-600$ & $350-725$ \\
\hline & Caenis robusta (Eaton, 1884) & le & 12 & nd & $300-500$ & $419-1685$ \\
\hline Ephemeridae & Ephemera danica (Müller, 1764) & lo & 1 & 4 & $200-1200$ & 838 \\
\hline \multirow[t]{2}{*}{ Leptophlebiidae } & Habrophlebia fusca (Curtis, 1834) & lo & 2 & nd & - & $425-910$ \\
\hline & Habrophlebia lauta (Eaton, 1884) & lo & 2 & nd & $200-1200$ & $930-1907$ \\
\hline Siphlonuridae & Siphlonurus aestivalis (Eaton, 1903) & lo & 1 & 3 & $200-800$ & 665 \\
\hline
\end{tabular}

Red list for Switzerland (Sartori et al., 1994): nd, status not defined; 3 = endangered; 4 = potentially endangered. le, lentic taxa; lo, lotic taxa

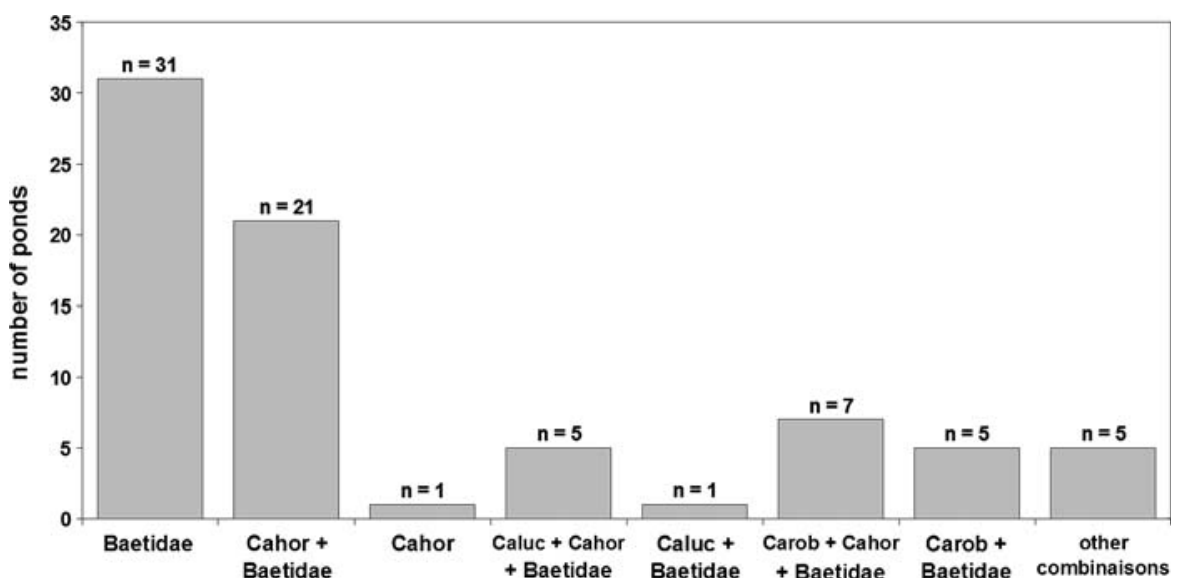

Fig. 1 Distribution of the mayflies among the 76 ponds containing Ephemeroptera. $n=$ number of ponds. cahor $=$ Caenis horaria; caluc = Caenis luctuosa; carob = Caenis robusta . The case of "other combinaisons" comprises: three ponds with

only present when Baetidae were present (with one exception). However, considering the selected environmental and physico-chemical variables, these were found to have no relevance in differentiating the ponds between sites with the presence of both Baetidae and Caenidae and sites with Baetidae alone. Only $3 \%$ of the variability given by the between-class
Baetidae + another family than Caenidae, one pond with Leptophlebiidae only and one pond with three families: Baetidae, Caenidae and Leptophlebiidae

PCA could be explained by environmental and physico-chemical variables. The Monte Carlo $P$ value was not significant for the parameters tested $(P=0.654)$.

Out of the 40 ponds containing Caenidae, Caenis horaria was found once alone, while in most cases (52\%, Fig. 1) its presence was associated with the 
Baetidae family. Otherwise, with the presence of Baetidae in most cases, C. luctuosa was observed together with Caenis horaria (12\% of cases, only once alone). Caenis robusta was associated with Caenis horaria (17\%) or without (13\%). Cloeon simile could be observed alone, or in combination with Cloeon dipterum, and/or Caenis horaria, and/or Caenis robusta and/or even Caenis luctuosa. But Caenis luctuosa and Caenis robusta were never found in the same pond together.

Mayflies and eutrophication

There was no significant difference in the values of the trophic state variables (concentration of TP, TN or conductivity) between the group of ponds with Cloeon dipterum (or Caenis horaria) present and the group of ponds without the species (Mann-Whitney $U$ test; $P>0.05$, see Table 4$)$. Nevertheless the relationship between TP and Cloeon dipterum was near to being significant $(P=0.085)$.

There was also no significant difference of the mayfly species richness present between the groups of ponds based upon their trophic state (TP, TN or conductivity). However, the relationship between eutrophic and hypertrophic ponds for TP (Fig. 2) was also almost significant (Mann-Whitney $U$ test; $P=0.096$ ).

Generalised Additive Model regressions were calculated for the two most frequent taxa, Caenis horaria and Cloeon dipterum. Table 5 presents the most relevant variables (two variables for Cloeon dipterum, four for Caenis horaria) retained in the two final regression models at $P=0.05$ level and their

Table 4 Signification ( $P$-values) of the differences for three trophic state variables between the group of ponds with Cloeon dipterum (or Caenis horaria) present and the group of ponds without the species (Mann-Whitney $U$ test)

\begin{tabular}{lll}
\hline Trophic state variables & Cloeon dipterum & Caenis horaria \\
\hline $\begin{array}{l}\text { Total phosphorus }(\mathrm{TP}) \\
(\mu \mathrm{g} \mathrm{P} / \mathrm{l})\end{array}$ & 0.085 & n.s. \\
$\begin{array}{l}\text { Total nitrogen }(\mathrm{TN}) \\
\quad(\mathrm{mg} \mathrm{N} / \mathrm{l})\end{array}$ & n.s. & n.s. \\
$\begin{array}{l}\text { Conductivity } \\
(\mu \mathrm{S} / \mathrm{cm})\end{array}$ & n.s. & n.s. \\
\hline
\end{tabular}

n.s. $=$ not statistically significant $(P>0.05)$. Value of $P$ is indicate if near to significance $(0.05<P<0.10) . n=71$ ponds (from colline and montane vegetation belts)

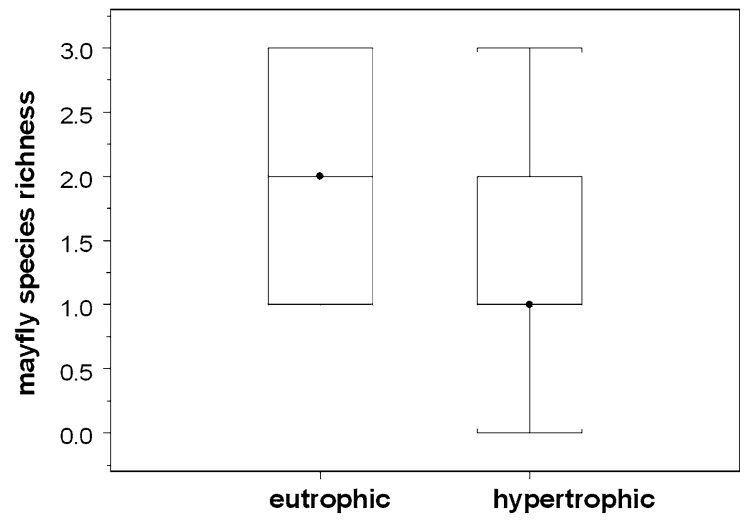

Fig. 2 Differences near level of significance (Mann-Whitney $U$ test; $P=0.096$ ) in mayfly species richness (box-plots) between groups of ponds based upon the trophic state of TP. Oligotrophic and mesotrophic box-plots are not showed, thus they were no significant difference for these trophic states. $n=71$ ponds (from colline and montane vegetation belts). Each box represents the interquartile distance (25-75\%) with the horizontal lines indicating the median. Upper error bars indicate the non-outlier maximum. Lower error bars indicate the non-outlier minimum

relative contributions. Cross-validation ratios were high for both models, with $\mathrm{r}$ above 0.7 . Consequently, regarding $r^{2}$ values, more than $50 \%$ of the species' distribution could be explained by the two, respectively the four variables retained in the models. The models explained between $14.6 \%$ and $32.1 \%$ of the deviance for Cloeon dipterum and Caenis horaria respectively. The response curves for the variables retained in the models are presented in Fig. 3. Confidence intervals were usually wider at both ends of all gradients where there were fewer observations. For both species, the regression models showed one similar trend: the linear positive influence of area. This finding indicates that the two species were more frequently associated with larger sized ponds than with smaller ones. Also for both species, the trophic state of the pond was a significant variable, although the shape of the response curve was different for each species explaining that Caenis horaria was mostly present in oligotrophic ponds, while Cloeon dipterum was associated mainly with eutrophic ponds. The model for Caenis horaria incorporated two more variables: mean depth which showed a complex response curve that seemed incoherent; and macrophytes species richness which showed a bell-shaped response curve: Caenis horaria seemed therefore to be associated with species-rich ponds. 
Table 5 Contributions of the explanatory variables and diagnostic parameters for the GAM of Cloeon dipterum and Caenis horaria at $P=0.05$ level. GAMs included 71 ponds from colline and montane vegetation belts

\begin{tabular}{|c|c|c|c|c|c|c|c|}
\hline \multirow[t]{2}{*}{ Taxon } & \multirow[t]{2}{*}{$n$} & \multicolumn{4}{|c|}{ Explanatory variables } & \multicolumn{2}{|c|}{ Diagnostic parameters } \\
\hline & & Area & $\begin{array}{l}\text { Total } \\
\text { phosphorus (TP) }\end{array}$ & Mean depth & $\begin{array}{l}\text { Macrophyte } \\
\text { species richness }\end{array}$ & $\begin{array}{l}\text { Explained } \\
\text { deviance }(\%)\end{array}$ & $\begin{array}{l}\text { Linear } \\
\text { correlation } \\
\text { ratio }\left(r^{2}\right)\end{array}$ \\
\hline Cloeon dipterum & 63 & 5.4 & 5.5 & - & - & 14.6 & 0.748 \\
\hline Caenis horaria & 29 & 4.5 & 2.5 & 2.5 & 2.7 & 32.1 & 0.716 \\
\hline
\end{tabular}

$n$, number of ponds where the species was present. area $=\log _{\mathrm{e}}$ transformed $\mathrm{m}^{2}$; total phosphorus $(\mathrm{TP})=$ transformed into one of the four trophic categories as described by OECD (1982); mean depth $=\log _{\mathrm{e}}$ transformed cm; macrophyte species richness $=$ not transformed

Fig. 3 Response curves for the variables incorporated in the Generalized Additive Models (GAMs) calculated for the presence of (a) Cloeon dipterum and (b) Caenis horaria. The dashed lines are approximate $95 \%$ confidence intervals around the smooth function lines. area $=\log _{\mathrm{e}}$ transformed $\mathrm{m}^{2}$; total phosphorus $(\mathrm{TP})=$ transformed into one of the four trophic categories as described by OECD (1982); mean depth $=\log _{\mathrm{e}}$ transformed $\mathrm{cm}$; macrophyte species richness $=$ not transformed. Vertical axes are scaled according to the dimensionless linear predictor
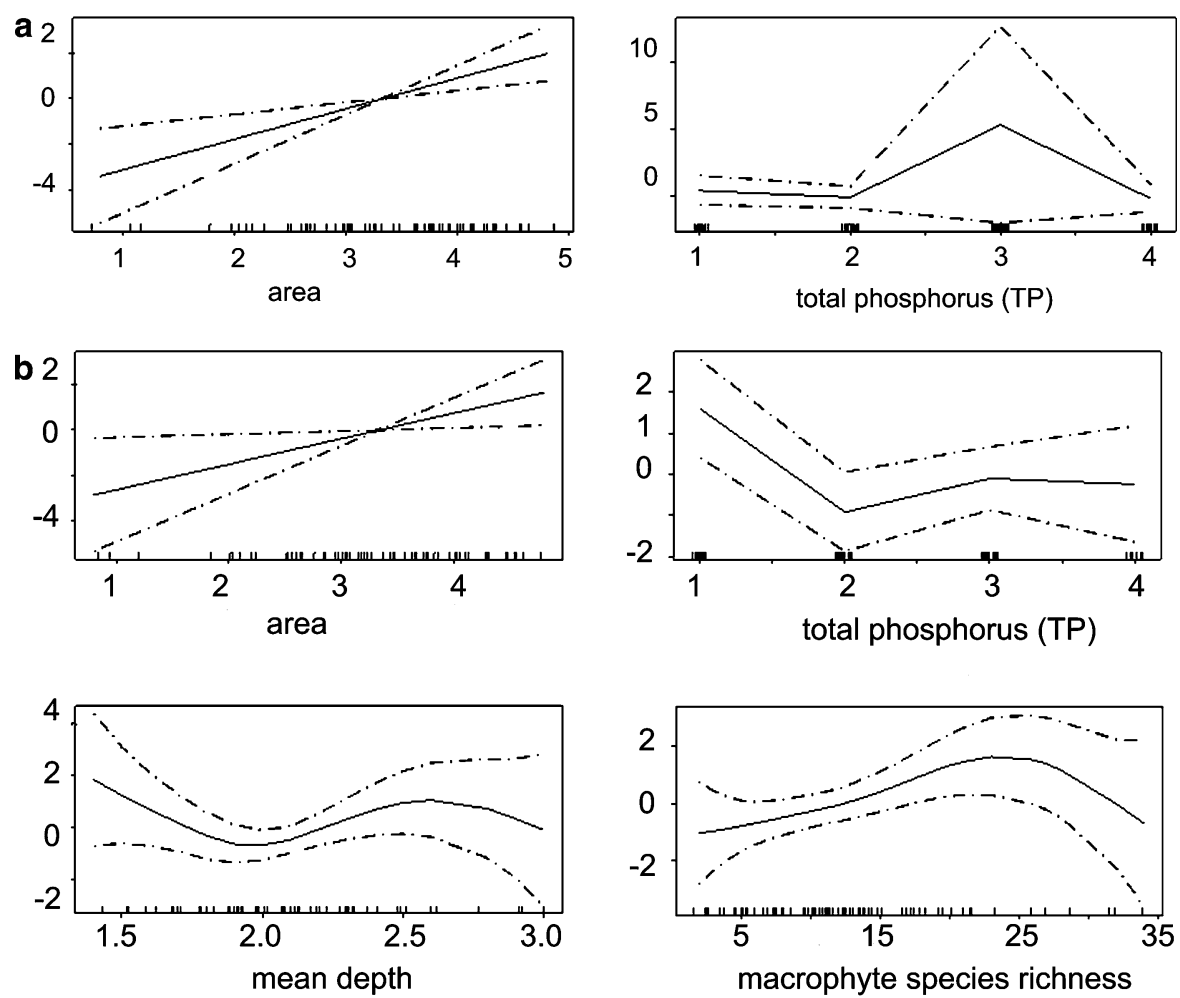

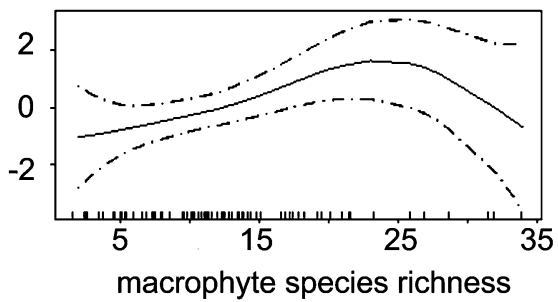

\section{Discussion}

Ephemeroptera species distribution in ponds

The Ephemeroptera are particularly well represented, being observed in $93 \%$ of the lowland ponds (colline and montane). Nevertheless, in terms of species richness, they are relatively poorly represented (mean species number $=1.9$ ). This is mainly due to the fact that most mayflies are adapted to living in running waters where the environmental conditions are drastically different from those of standing waters. Both Caenidae and Baetidae families contain some of the most resistant species to organic pollution and to low levels of oxygen (Macan, 1973; Brönmark \& Hansson, 2000). Two species dominate our data group: Cloeon dipterum and Caenis horaria, both of which are known to be very resistant to eutrophic conditions (group 6 in Soldán et al., 1998, or groups E-G in Kelly-Quinn \& Bracken, 2000).

Only a few additional mayfly species could potentially be observed in Swiss ponds. These are: 
Leptophlebia marginata, Leptophlebia verspertina, Rhithrogena loyolaea (above altitude of 2,800 m), Ephemera glaucops (recently discovered in one location in eastern Switzerland); Ecdyonurus sp. (in drift conditions or at altitude), Paraleptophlebia werneri (elsewhere) and perhaps Arthroplea congener (although at present only found in Germany and Austria). Interestingly, all these species mentioned are rare species and found in special conditions.

Many of our observations include new localities for Switzerland's Ephemeroptera, and therefore will contribute to the updating of the geographical distribution of the species presented in Sartori and Landolt (1999). Furthermore, altitudinal ranges presented by these authors will be largely revised, with new data for 7 out of the 12 species found in the sampled ponds (see Table 3).

Mayflies and eutrophication

Ephemeroptera species richness has a negative relationship with an increase of eutrophication (based on TP). Nevertheless, the presence of Ephemeroptera species in the studied ponds cannot be explained by the trophic state alone, since all simple direct relationships between the presence of Caenis horaria and Cloeon dipterum and the trophic state of water are not significant. However, in the model, taking into account the other predominant environmental variables (i.e. altitude, area, mean depth and macrophyte species richness), trophic state, based on TP, is significant. The two species appear to avoid hypertrophic ponds. Their optimum conditions are oligotrophic for Caenis horaria and eutrophic for Cloeon dipterum. This relationship with trophic conditions has already often been demonstrated in running water studies. For example, in Tachet et al. (2000), the biological traits for Caenis sp. indicate that mesotrophic conditions are optimal for this genera. Contrastingly, Cloeon sp. could be found in either mesotrophic or eutrophic habitats. Furthermore, Baetidae appears as one of the Ephemeropteran families the most tolerant to organic pollution. For example, Cloeon dipterum is the European species that exhibits the greatest saprobic index among mayflies $(\mathrm{SI}=2.6)$ making it a characteristic element of $\beta-\alpha$ mesosaprobic conditions. Caenis horaria and $C$. robusta are ranked as less tolerant $(\mathrm{SI}=2.2)$ and more confined to $\beta$ mesosaprobic environments (Moog, 1995; Moog et al., 1997).

Following these relations, a really interesting observation was made on the association of the two most common families observed in the ponds sampled. Baetidae is observed as the only Ephemeroptera family present in several ponds. This is not the case for Caenidae, which are found only if Baetidae are already present. This particularity has also been observed for several sets of water-bodies in the French Rhône and Ain floodplains (Castella et al., 1984, 1991; Castella, 1987).

The presence of Caenidae alongside Baetidae, could be important for bioassessment work. As the potential number of mayfly species in such environment is normally low (five in general), the occurrence of an additional species from the Caenidae family may have some significance with regard to environmental conditions. On the contrary, the presence of rare species in ponds seems to depend more on special conditions than on trophic states. This finding represents an important development for the use of Ephemeroptera as bioindicators in Switzerland. Therefore, frequently observed species like Caenis sp. and Cloeon sp. seem to be more suitable to assess the trophic state of ponds (as demonstrated in this study).

The fact that Caenidae are more often absent from sampled ponds than Baetidae could be a discrepancy in the sampling dates among ponds. One hypothesis could be that Caenidae were not present in ponds sampled in late summer because the adult emergence occurs earlier in the season and before the sampling session. Caenis sp. shows large variations in their life history patterns as demonstrated for Caenis luctuosa by Cayrou \& Cereghino (2003) and for Caenis horaria and Caenis luctuosa by Oertli (1992) and Bänziger (2000). Nevertheless, the population dynamics presented by these authors demonstrate that individuals of Caenis sp. are present in the water throughout the year (even if their repartition in size classes largely varies); This being the case, the time of sampling is probably not an explanation for the absence of this taxa. An alternative explanation could be the capacity of dispersion and colonisation since it is known that this capacity is greater for Baetidae than for Caenidae. Furthermore, Cloeon dipterum is relatively well known as a pioneering coloniser of new waterbodies and of temporary habitats (Sartori \& 
Landolt, 1999). The explanation of Cloeon dipterum's "success story" is to be found in its peculiar biology, ecology, and physiology. It is one of the rare ovoviviparous species in Europe, with females having an unusual life span of about 2 weeks during which the whole embryonic development takes place in the genital ducts (Degrange, 1959; Soldán, 1979). Females are often found quite far from the waterbody where they were born and disperse actively towards new habitats, making it a true colonizer species. Finally nymphs are detritivorous (Brown, 1961; Cianciara, 1980) and can afford very low levels of oxygen concentration, even anoxia in some conditions (Nagell, 1977a, b; Nagell \& Fagerström, 1978) and seem tolerant to rapid temperature changes (McKee \& Atkinson, 2000). These traits enable $C$. dipterum to be very successful in small ponds where it encounters few competitors. In fact, this species is known to be relatively independent of environmental factors. Another hypothesis is that ponds where only Baetidae are present are young ponds or temporary ponds. However, this is not supported by our data since only 12 of the 71 ponds containing Baetidae are younger than 25 years old. Furthermore they are all permanent ponds. Therefore, the most likely explanation of this singularity is the trophic state of ponds as discussed in the previous section.

In conclusion, our study has demonstrated that there is a great potential in using mayflies as bioindicators for the management of the water quality of ponds. Indeed, a relationship with the trophic state of ponds is hereby revealed for Ephemeroptera species richness and for the presence of Caenis horaria and Cloeon dipterum. These findings allow us to propose two new metrics for the water assessment of Swiss ponds: first, the Ephemeroptera species richness and second the presence of Caenidae associated with Baetidae. Nevertheless, these metrics need to be tested before being integrated into routine monitoring. Furthermore, other investigations must be made to confirm the suitability of these pond bioindicators for areas outside of Switzerland. Moreover, as these two metrics are only based on a small number of species, it would be necessary to use them in conjunction with other metrics to enable accurate assessments. Other such metrics, based on species or families richness (from macroinvertebrates and macrophytes assemblages), are currently in development (Hering et al., 2004; Menetrey et al., 2005; Furse et al., 2006). These should help to put into practice a scientific-based management of water quality in ponds as required for other waterbodies by the European Water Framework Directive.

Acknowledgements We are grateful to our collaborators Christiane Ilg, Hélène Hinden, Marc Pellaud, Gilles Carron, Amaël Paillex and Dominique Auderset-Joye for their help in the field and laboratory work. The authors appreciate also the great help and constructive comments from Emmanuel Castella. Thanks to the CSCF for the access to the Swiss databanks on fauna, Swiss National Park for collaboration studies, Nathalie Rimann and Emilie Hafner for access to a subset of the pond data. Thanks to David McCrae for his great help in improving the English style. Previous help in identification was provided by Diana Cambin. We are also grateful to the Bourse Augustin Lombard of the "Société de physique et d'histoire naturelle de Genève (SPHN)" and the "Office of Environment and Energy" of the canton of Luzern for their financial support. Finally, thanks to the water agencies of the cantons of Geneva and Vaud for completing some of the chemical analyses of the water samples. The database was in great part provided by the previous PLOCH study, financially supported by the "Swiss Agency for the Environment, Forests and Landscape".

\section{References}

AFNOR, 1992. Détermination de l'Indice Biologique Global Normalisé (IBGN). Norme française T 90-350. Association française de normalization, Paris.

Bänziger, R., 2000. Spatio-temporal distribution of size classes and larval instars of aquatic insects (Ephemeroptera, Trichoptera and Lepidoptera) in a Potamogeton pectinatus L. bed (Lake Geneva, Switzerland). Revue Suisse de Zoologie 107: 139-151.

Barbour, M. T., J. Gerritsen, B. D. Snyder \& J. B. Stribling, 1999. Rapid Bioassessment Protocols for Use in Streams and Wadeable Rivers: Periphyton, Benthic Macroinvertebrates and Fish, 2nd edn. EPA 841-B-99-002, Office of Water, U.S. Environmental Protection Agency, Washington.

Bauernfeind, E. \& O. Moog, 2000. Mayflies (Insecta: Ephemeroptera) and the assessment of ecological integrity: a methodological approach. Hydrobiologia 422: 71-83.

Biggs, J., P. Williams, M. Whitfield, G. Fox \& P. Nicolet, 2000. Biological techniques of still water quality assessment: phase 3. Method development. P. Action. R\&D Technical Report E56. Environment Agency, Bristol.

Boix, D., S. Gascon, J. Sala, M. Martinoy, J. Gifre \& X. D. Quintana, 2005. A new index of water quality assessment in Mediterranean wetlands based on crustacean and insect assemblages: the case of Catalunya (NE Iberian peninsula). Aquatic Conservation: Marine and Freshwater Ecosystems 15: 635-651.

Brönmark, C. \& L. A. Hansson, 2000. The biology of Lakes and Ponds. In Crawley, M., C. Little, T. R. E. Southwood, S. Ulfstrand (eds), Biology of Habitats, 285 Sidor. Oxford University Press, New York. 
Brown, D. S., 1961. The food of the larvae of Cloeon dipterum L. and Baetis rhodani (Pictet) (Insecta, Ephemeroptera). Journal of Animal Ecology 30: 55-75.

Castella, E., 1987. Apport des macroinvertébrés aquatiques au diagnostic écologique des écosystèmes abandonnés par les fleuves. Recherches methodologiques sur le Haut-Rhône français. Université Claude Bernard - Lyon 1, Lyon.

Castella, E., M. Richardot-Coulet, C. Roux \& P. Richoux, 1984. Macroinvertebrates as describers of morphological and hydrological types of aquatic ecosystems abandoned by the Rhone River. Hydrobiologia 119: 219-226.

Castella, E., M. Richardot-Coulet, C. Roux \& P. Richoux, 1991. Aquatic macroinvertebrate assemblages of two contrasting floodplains: the Rhône and Ain rivers, France. Regulated Rivers: Research \& Management 6: 289-300.

Cayrou, J. \& R. Cereghino, 2003. Life history, growth and secondary production of Caenis luctuosa and Cloeon simile (Ephemeroptera) in a small pond, SW France. Aquatic Insects 25: 191-201.

Cianciara, S., 1980. Food preference of Cloeon dipterum (L. larvae and dependence of their development and growth on the type of food. Polskie Archiwum Hydrobiologii 27: $143-160$.

Degrange, C., 1959. L'ovolarviparité de Cloeon dipterum (L.) (Ephemereptera, Baetidae). Bulletin de la Société Zoologique de France 64: 94-100.

Furse, M., D. Hering, O. Moog, P. Verdonschot, L. Sandin, K. Brabec, K. Gritzalis, A. Buffagni, P. Pinto, N. Friberg, J. Murray-Bligh, J. Kokes, R. Alber, P. Usseglio-Polatera, P. Haase, R. Sweeting, B. Bis, K. Szoszkiewicz, H. Soszka, G. Springe, F. Sporka \& I. Krno, 2006. The STAR project: context, objectives and approaches. Hydrobiologia 566: 3-29.

Hering, D., O. Moog, L. Sandin \& P. F. M. Verdonschot, 2004. Overview and application of the AQEM assessment system. Hydrobiologia 516: 1-20.

Hickey, C. W. \& W. H. Clements, 1998. Effects of heavy metals on benthic macroinvertebrate communities in New Zealand streams. Environmental Toxicology and Chemistry 17: $2338-2346$.

Hieber, M., C. T. Robinson, U. Uehlinger \& J. V. Ward, 2005. A comparison of benthic macroinvertebrate assemblages among different types of alpine streams. Freshwater Biology 50: 2087-2100.

Hubbard, M. D. \& W. L. Peters, 1978. Environmental requirements and pollution tolerance of Ephemeroptera. EPA 600-4-78-061 U.S. Environmental Protection Agency, Cincinnati, OH, VI.

Kelly-Quinn, M. \& J. J. Bracken, 2000. Ephemeropteran assemblages in Ireland. Verhandlungen Internationale Vereinigung für Theoretische und Angewandte Limnologie 27: 963-969.

Kerans, B. L. \& J. R. Karr, 1994. A benthic index of biotic integrity (B-Ibi) for rivers of the Tennessee valley. Ecological Applications 4: 768-785.

Lehmann, A., J. M. Overton \& J. R. Leathwick, 2002. GRASP: generalized regression analysis and spatial prediction. Ecological Modelling 157: 189-207.

Lenat, D. R., 1988. Water quality assessment of streams using a qualitative collection method for benthic macroinvertebrates. Journal of the North American Benthological Society 7: 222-233.

Lenat, D. R. \& D. L. Penrose, 1996. History of the EPT taxa richness metric. Bulletin of the North American Benthological Society 12: 305-306.

Macan, T. T., 1973. Ponds and Lakes. G. A. U. Ltd., London.

Madenjian, C. P., D. W. Schloesser \& K. A. Krieger, 1998. Population models of burrowing mayfly recolonization in western Lake Erie. Ecological Applications 8: 1206-1212.

McKee, D. \& D. Atkinson, 2000. The influence of climate change scenarios on populations of the mayfly Cloeon dipterum. Hydrobiologia 441: 55-62.

Menetrey, N., L. Sager, B. Oertli \& J.-B. Lachavanne, 2005. Looking for metrics to assess the trophic state of ponds. Macroinvertebrates and amphibians. Aquatic Conservation: Marine and Freshwater Ecosystems 15: 653-664.

Metcalfe, J. L., 1989. Biological water quality assessment of running waters based on macroinvertebrate communities: history and present status in Europe. Environmental Pollution 60: 101-139.

Moog, O., 1995. Fauna aquatica Austriaca. Katalog zur autökologischen Einstufung Aquatischer Organismen Osterreichs. O. Moog. Fauna aquatica Austriaca. Abteilung für Hydrobiologie, Fischereiwirtschaft und Aquakultur des Universität für Bodenkultur, Wien.

Moog, O., E. Bauernfeind \& P. Weichselbaumer, 1997. The use of Ephemeroptera as saprobic indicators in Austria. In Landolt, P. \& M. Sartori Fribourg, (eds), Ephemeroptera \& Plecoptera. Biology-Ecology-Systematics, Mauron, Tinguely \& Lachat SA, 254-260.

Nagell, B., 1977a. Phototactic and thermotactic responses facilitating survival of Cloeon dipterum (Ephemeroptera) larvae under winter anoxia. Oikos 29: 342-247.

Nagell, B., 1977b. Survival of Cloeon dipterum (Ephemeroptera) larvae under anoxic conditions in winter. Oikos 29: 161-165.

Nagell, B. \& T. Fagerström, 1978. Adaptations and resistance to anoxia in Cloeon dipterum (Ephemeroptera) and Nemoura cinerea (Plecoptera). Oikos 30: 95-99.

OECD, 1982. Eutrophication of Waters: Monitoring, Assessment and Control. Organization of Economic Cooperation and Development (OECD), Paris.

Oertli, B., 1992. L'influence de trois substrats (Typha, Chara, feuilles mortes) d'un étang forestier sur la densité, la biomasse et la production des macroinvertébrés aquatiques. Faculté des Sciences, LEBA, Université de Genève.

Oertli, B., D. Auderset Joye, E. Castella, R. Juge \& J.-B. Lachavanne, 2000. Diversité biologique et typologie écologique des étangs et petits lacs de Suisse. OFEFP. LEBA, Université de Genève, Genève.

Oertli, B., J. Biggs, R. Cereghino, P. Grillas, A. Jolly \& J.-B. Lachavanne, 2005a. Conservation and monitoring of pond biodiversity: introduction. Aquatic Conservation: Marine and Freshwater Ecosystems 15: 535-540.

Oertli, B., D. Auderset Joye, C. Castella, R. Juge, A. Lehmann \& J.-B. Lachavanne, 2005b. PLOCH: a standardized method for sampling and assessing the biodiversity in ponds. Aquatic Conservation: Marine and Freshwater Ecosystems 15: 665-679. 
Resh, V. H. \& J. K. Jackson, 1993. Rapid assessment approaches to biomonitoring using benthic macroinvertebrates. In Rosenberg, D. M. \& V. H. Resh (eds), Freshwater Biomonitoring and Benthic Macroinvertebrates. Chapmann and Hall, V. H. New York: 159-194.

Sartori, M. \& P. Landolt, 1999. Atlas de distribution des éphémères de Suisse (Insecta, Ephemeroptera). Neuchâtel, Centre suisse de cartographie de la faune (CSCF/SZKF), Fauna Helvetica.

Sartori, M., P. Landolt \& P. A. Zurwerra, 1994. Liste rouge des éphémères de Suisse (Ephemeroptera). In Duelli, P. (ed.), Liste rouge des espèces animales menacées de Suisse. Office fédéral de l'environnement, des forêts et du paysage (OFEFP), Berne, 72-74.

Schloesser, D. W. \& T. F. Nalepa, 2002. Comparison of 5 benthic samplers to collect burrowing mayfly nymphs (Hexagenia spp: Ephemeroptera: Ephemeridae) in sediments of the Laurentian Great Lakes. Journal of the North American Benthological Society 21: 487-501.

Sladecek, V., 1973. System of water quality from the biological point of view. Archiv fur Hydrobiologie, Beiheft Ergebnisse der Limnologie 7: 1-218.
Soldán, T., 1979. The structure and development of the female internal reproductive system in six European species of Ephemeroptera. Acta Entomologica Bohemoslovaca 76: 353-365.

Soldán, T., S. Zahradkova, J. Helesic, L. Dusek \& V. Landa, 1998. Distributional and quantitative patterns of Ephemeroptera and Plecoptera in the Czech republic: a possibility of detection of long-term environmental changes of aquatic biotopes. Folia Facultatis Scientiarum Naturalium Universitatis Masarykianae Brunensis 98: 1305.

Tachet, H., P. Richoux, M. Bournaud \& P. Usseglio-Polatera, 2000. Invertébrés d'eaux douces. Systématique, biologie, écologie. CNRS Editions, Paris.

Wetzel, R. G., 1983. Limnology, 2nd edn. CBS College Publishing, New York.

Wright, J. F., M. T. Furse \& D. Moss, 1998. River classification using invertebrates: RIVPACS applications. Aquatic Conservation: Marine and Freshwater Ecosystems 8: 617631. 